\title{
FAKTOR-FAKTOR PENGHAMBAT PELAKSANAAN GERAKAN PEMBANGUNAN DESA (GERBANG DESA) MELALUI PROGRAM INFRASTRUKTUR
}

\author{
Andi Yusuf Katili \\ STIA Bina Taruna Gorontalo \\ yusuf2801@gmail.com
}

\begin{abstract}
ABSTRAK
Penelitian ini bertujuan untuk memberikan gambaran mengenai faktor-faktor penghambat pelaksanaan gerakan pembangunan desa melalui program infrastruktur di Desa Bulalu Kecamatan Kwandang Kabupaten Gorontalo Utara. Jenis penelitian yang digunakan dalam penelitian ini adalah jenis penelitian deskripsi kualitatif. Pengumpulan data dilakukan melalui observasi, wawancara dan dokuemntasi. Wawancara dilakukan kepada sejumlah informan yang telah ditentukan yaitu yang memiliki kompetensi yang berkaitan dengan tujuan penelitian.

Hasil penelitian menyimpulkan, bahwa Perencanaan Kegiatan yang dilakukan oleh Pemerintah Desa belum maksimal dilaksanakan sebagaimana mestinya karena tidak melibatkan masyarakat miskin dalam menentukan skala prioritas usulan yang akan dikerjakan; Sumber Daya Manusia (SDM) dan keahlian yang dimiliki oleh Tim Pelaksana Kegiatan Desa (TPKD) belum memenuhi syarat menjadi pelaksana kegiatan Desa; Pemanfaatan Sumber daya alam (SDA) serta pemanfaatan tenaga kerja lokal oleh pemerintah desa dalam pembangunan infrastruktur berupa pembangunan jalan belum dilaksanakan.

Berdasarkan uraian maka disarankan Pemerintah Desa Bulalo Kecamatan Kwadang: perlu melibatkan masyarakat miskin dalam hal penentuan skala prioritas usulan yang akan dilakukan; perlu melibatkan masyarakat yang memiliki Sumber daya manusia (SDM) dan keahlian khusus untuk menjadi Tim Pelaksana Kegiatan Desa (TPKD) sehingga Pembangunan Desa bisa mencapai target yang telah ditentukan; Pemerintah Desa Bulalo harus memanfaatkan potensi sumber daya alam (SDA) yang ada di Desa itu sendiri, yaitu melibatkan tenaga kerja lokal dalam pelaksanaan pekerjaan infrastruktur di Desa, sehingga selain masyarakat mendapatkan penghasilan dari pekerjaan tersebut juga melancarkan progres kegiatan pekerjaan sesuai dengan target yang telah ditentukan; Pemerintah Daerah Kabupaten Gorontalo Utara perlu melakukan pemantauan dan pengawasan semua tahapan pelaksanaan kegiatan pembangunan yang ada di Desa Bulalo Kecamatan Kwandang Kabupaten Gorontalo Utara.
\end{abstract}

Kata Kunci: Pelaksanaan, Gerakan, Pembangunan, Desa

\begin{tabular}{cccl}
\hline \multicolumn{2}{c}{ PENDAHULUAN } & dilaksanakan adalah untuk \\
Pada & Hakekatnya & tujuan & menyejahterakan masyarakat. Hal ini \\
pembangunan & suatu & Negara & seperti tertuang dalam Pembukaan
\end{tabular}


Undang-Undang Dasar 1945 dinyatakan bahwa tujuan Pembangunan Nasional Bangsa Indonesia adalah melindungi segenap bangsa dan seluruh tumpah darah Indonesia, memajukan kesejahteraan umum, mencerdaskan kehidupan bangsa, serta ikut melaksanakan ketertiban dunia. Untuk mewujudkan tujuan tersebut dilaksanakan pembangunan nasional, yaitu pembangunan manusia Indonesia seutuhnya dan pembangunan masyarakat seluruhnya.

Dalam merealisasikan tujuan pembangunan, maka segenap potensi alam harus digali, dikembangkan, dan dimanfaatkan sebaik-baiknya. Begitu pula dengan Potensi manusia berupa penduduk yang banyak jumlahnya harus ditingkatkan pengetahuan dan keterampilannya sehingga, mampu menggali, mengembangkan dan memanfaatkan potensi alam secara maksimal, dan pelaksanaan program pembangunan tercapai Berbagai rencana dan program-program pembangunan sebagai wujud pelaksanaan pemerintahan telah dibuat dan diimplementasikan di daerah kecamatan, dan desa baik yang dilaksanakan oleh pemerintah pusat melalui Instansi-instansi vertikal di daerah, maupun pemerintah itu sendiri. Salah satu program pemerintah yaitu pembangunan yang dilaksanakan oleh masyarakat secara swadaya, atau oleh lembaga-lembaga non-pemerintah lainnya yang memiliki program-program pembangunan berupa pemberdayaan masyarakat.

Dalam mewujudkan tujuan program pembangunan pada setiap lembaga dibutuhkan suatu pola manajerial dalam pengelolaan pembangunan, pola manajerial tersebut dimaksudkan agar hasil pembangunan dan program-program pemerintahan lainnya dapat dirasakan dan dinikmati manfaatnya oleh masyarakat. Salah satu hal yang dibutuhkan adalah kesadaran dan partisipasi aktif dari seluruh masyarakat dalam menunjang suksesnya pelaksanaan program pembangunan. Selain itu juga diperlukan kebijaksanaan pemerintah untuk mengarahkan serta membimbing masyarakat untuk bersama-sama melaksanakan program pembangunan.

Akibat dari jumlah masyarakat miskin makin besar jumlahnya kesenjangan terjadi cenderung ratarata 6,5 persen pertahun.sehingga perlu dicari penangulangannya,padahal saat ini Indonesia harus sudah bersiap-siap menyongsong era keterbukaan ekonomi dengan ditandai meningkatkan persaingan antar ekonomi yaitu dengan cara mensejajarkan diri dengan Negaranegara yang sudah maju. tekad tersebut tentu akan menghadapi banyak kendala sebab kondisi Negara yang serba kekurangan bahkan sampai pada tingkatan kebutuhan paling dasar yaitu kebutuhan akan pangan sangat sulit diatasi sehinga masyarakat tidak mampu memenuhi standar hidup,kondisi rawan pangan melanda sebagian masyarakat baik di wilayah perkotaan maupun di wilayah pedesaan, apabila kondisi rawan pangan ini tidak segera diatasi maka pada giliranya kestabilan suatu pemerintahan atau suatu daerah akan goyah oleh karena itu melalui dana angaran pendapatan belanja Negara $(\mathrm{APBN})$ dan dana konpenisasi bahan bakar minyak (BBM) pemerintah melalui daerah mengucurkan dana 
bantuan untuk rakyat miskin yaitu dengan program bantuan beras miskin (RASKIN) dalam hal ini ada 2 macam program beras miskin (RASKIN) yakni dananya yang bersumber dari angaran pendapatan belanja Negara (APBN) dan dari dana konpenisasi kenaikan harga Bahan bakar minyak (BBM), Program Bantuan Siswa Miskin di khususkan untuk siswa dari keluarga miskin, Program Simpanan Keluarga Sejahtera diperuntukan kepada keluarga yang kurang mampu berupa bantuan uang tunai, Program Imprastruktur, serta basih banyak lagi program-program bantuan untuk masyarakat yang diambil dari APBN seperti Dana Desa yang diperuntukan untuk pembangunan Desa itu sendiri serta pengelolaannya di serahkan ke Desa tersebut, serta anggaran program APBD daerah itu sendiri. Dalam proses mempercepat pembangunan Desa sebagai mana yang diharapkan oleh Pemerintah Pusat, sebagai mana panduan pelaksanaan pembangunan desa, pemerintah desa harus melaksanakan tahapan-tahapan antara lain: 1) Perencanaan Kegiatan. 2) Pelaksanaan Kegiatan. 3) Pengawasan. Perencanaan kegiatan adalah proses musyawarah yang dilakukan oleh lembaga Desa dalam hal ini BPD dan pemerintah desa dan melibatkan seluruh masyarakat desa, guna untuk menentukan usulanusulan skala prioritas yang disesuaikan dengan letak permasalahan yang dialami langsung oleh masyarakat usulan interfensi negatif dari orang perorang yang hanya ingin mengambil keuntungan sepihak saja dan didokumenkan melalui dokumen Rencana Pembangunan Jangka Menengah (RPJMDes) dan Rencana Kegiatan
Pembangunan Desa (RKPDes). Dalam dokumen tersebut memuat semua usulan-usulan masyarakat dalam jangka lima tahunan dan usulan masyarakat tahunan. Tim Pelaksana Kegiatan Desa yang dibentuk langsung oleh Pemerintah Desa untuk bertanggung jawab langsung pada proses pelaksanaan kegiatan, tim pelaksana kegiatan Desa tersebut dipilih langsung dari tokoh masyarakat yang memiliki sumber daya manusia (SDM) atau keahlian khusus dalam keuangan, ketekhnisan, maupun kegiatankegiatan kemasyarakatan, dengan mengedepankan keterbukaan dalam pelaksanaan kegiatan. Pengawasan terhadap kegiatan yang dilakukan oleh Badan Permusyawaratan Desa (BPD) serta masyarakat, termasuk pengawasan terhadap lokasi pembangunan program apakah sesuai dengan peruntukannya atau tidak, hal tersebut bertujuan agar proses kegiatan yang dilaksanakan oleh TPKD bisa berjalan dengan baik dan sesuai dengan apa yang menjadi harapan masyarakat. Ketiga tahapan tersebut apabila dilaksanakan sepenuhnya oleh Pemerintah Desa bersama lembaga Desa dalam hal ini BPD maka tujuan percepatan pembangunan akan terpenuhi sebagai mana target yang telah ditentukan. Hal ini dilakukan oleh Pemerintah Pusat untuk mempercepat gerakan pembangunan yang ada di Daerah, kecamatan dan Desa. Di Desa Bulalo Kecamatan kwandang Kabupaten Gorontalo Utara sebagai mana observasi awal dari peneliti terkait dengan Gerakan Pembangunan desa itu sendiri yaitu suatu gerakan atau tindakan bersama yang dilaksanakan oleh semua elemen yang terkait di Desa untuk melaksanakan suatu pembangunan melalui pembangunan 
fisik antara lain pembangunan MCK, Pembangunan Jalan Rabat Beton, dan pembangunan drainase, secara umum masih mengalami hambatan, hal itu disebabkan oleh beberapa faktor internal maupun eksternal sehingga pembangunan tersebut belum bisa memenuhi tingkat kesejahteraan masyarakat yang ada di Desa Bulalo itu sendiri.

Dalam proses musyawarah perencanaan pembangunan yang dilakukan oleh Pemerintah Desa dan Badan Permusyawaratan Desa (BPD) untuk menghasilkan program pembangunan infrastruktur seperti pembangunan MCK, Drainase, dan pembangunan Jalan Rabat beton yang ada kaitannya dengan kebutuhan masyarakat, namun sebahagian besar ke tiga program pembangunan tersebut yang dirumuskan melalui rapat musyawarah perencanaan itu tidak sesuai dengan kebutuhan sebahagian besar masyarakat miskin di Desa Bulalo, hal itu diakibatkan oleh Badan Permusyawaratan Desa (BPD) dan Pemerintah Desa dalam melaksanakan musyawarah perencanaan kegiatan pembangunan kurang melibatkan masyarakat miskin sehingga muncul interfensi dari pihak-pihak lain yang dengan sengaja ingin mengambil keuntungan secara sepihak saja.

Dalam Pelaksanaan kegiatan pembangunan imprastruktur yang dilaksanakan oleh tim pelaksana kegiatan (TPK) Desa Bulalo sering mengalami masalah contohnya dalam hal pembangunan infrastruktur MCK, pembangunan drainase, sering mengalami keterlambatan dalam pelaporan keuangan dan dan juga dalam penguasaan teknik pekerjaan itu yang tidak di miliki oleh Tim Pelaksana Kegiatan (TPK) Desa
Bulalo itu sendiri, hal itu diakibatkan oleh sebahagian besar tim pelaksana kegiatan desa (TPKD) Desa Bulalo yang di pilih oleh Pemerintah Desa Bulalo tidak memiliki sumber daya manusia (SDM) atau keahlian di bidang keteknisan dan keuangan.

Di sisi lain masalah yang muncul dalam pelaksanaan pembangunan MCK, Drainase, dan pembangunan Jalan Rabat beton yaitu masalah yang munculdari kalangan masyarakat. Faktor kecemburuan sosial yang bermunculan di kalangan masayarakat akibat dari dalam pemanfaatan Sumber daya alam (SDA) berupa bahan material Lokal seperti batu, kerikil, pasir oleh tim pelaksana kegiatan (TPK) tidak menggunakan bahan material yang ada di Desa itu sendiri, begitu juga dalam pemanfaatan tenaga kerja, tim pelaksana kegiatan (TPK) sebahagian besar meggunakan tenaga kerja di luar Desa Bulalo, padahal masih banyak tenaga kerja lokal yang ada di Desa.

\section{PERMASALAHAN}

Berdasarkan uraian tersebut, maka rumusan masalah dalam penelitian ini adalah Faktor-Faktor apa saja yang menjadi Penghambat Pelaksanaan Gerakan Pembangunan Desa (Gerbang Desa) Melalui Program Pembangunan Infrastruktur Di Desa Bulalo Kecamatan Kwandang Kabupaten Gorontalo Utara?

\section{TUJUAN DAN MANFAAT PENELITIAN}

Dalam penelitian ini, tujuan
yang dicapai yaitu r untuk
memperoleh gambaran tentang


Faktor-Faktor Penghambat

Pelaksanaan Gerakan Pembangunan Desa (Gerbang Desa) Melalui Program Pembangunan Infrastruktur Di Desa Bulalo Kecamatan Kwandang Kabupaten Gorontalo Utara.

\section{Fokus Penelitian}

Penelitian ini difokuskan pada:

\section{Perencanaan Kegiatan}

Perencanaan Kegiatan yang dimaksudkan dalam penelitian ini adalah Proses musyawarah perencanaan yang dilakukan oleh Pemerintah Desa Bulalo dalam penentuan skalaprioritas usulan pembangunan Desa.

\section{Sumber daya manusia (SDM)}

Sumber daya manusia (SDM) yang dimaksudkan dalam penelitian ini adalah sdm yang dimiliki oleh Tim Pelaksana Kegiatan Desa Bulalo dalam hal melaksanakan kegiatan pembangunan Desa.

Pemanfaatan Sumber daya alam (SDA) dan tenaga kerja lokal

Pemanfaatan Sumber daya alam (SDA) dan tenaga kerja lokal yang dimaksudkan dalam penelitian ini adalah Pemanfaatan Bahan material lokal berupa batu, pasir, kerikil, dan juga tenaga kerja yag ada di dalam desa untuk digunakan dalam pembangunan MCK, drainase, dan jalan rabat beton yang ada di Desa Bulalo.

\section{HASIL PENELITIAN DAN PEMBAHASAN}

Penelitian tentang Faktorfaktor penghambat pelaksanaan Gerakan Pembangunan Desa (Gerbang desa) melalui Program Pembangunan Infrastruktur di Desa Bulalo di Kecamatan Kwandang Kabupaten Gorontalo Utara itu sangat ditentukan pada fokus penelitian yaitu Perencanaan Kegiatan, Sumber Daya Manusia (SDM), Pemanfaatan Sumber daya alam (SDA) dan tenaga kerja lokal. Hasil analisis menunjukan bahwa ke tiga fokus utama tersebut ternyata menjadi faktor-faktor penghambat pelaksanaan gerakan pembangunan desa (gerbang desa) melalui Program Infrastruktur di Desa Bulalo Kecamatan Kwandang Kabupaten Gorontalo Utara.

Perencanaan kegiatan yang dilaksanakan oleh Pemerintah Desa Bulalo Kecamatan Kwandang Kabupaten Gorontalo Utara melalui Rapat Perencanaan Kegiatan untuk menentukan usulan pembangunan yang dibutuhkan oleh seluruh masyarakat miskin yang ada di Desa, belum dilaksanakan sebagaimana mestinya dengan ikut melibatkan masyarakat miskin dalam menentukan skala prioritas usulan yang akan dikerjakan, contohnya pembangunan jalan rabat beton, MCK, dan drainase.

Sumber Daya Manusia (SDM) yang dimiliki oleh Tim Pelaksana Kegiatan Desa (TPKD) Desa Bulalo Kecamatan Kwandang Kabupaten Gorontalo Utara tidak memadai, contohnya dari standar pendidikan yang dimiliki oleh Ketua TPKD hanya SMP, dan tidak memiliki keahlian khusus dalam pembangunan desa, begitu juga bendahara TPKD yang tidak memiliki keahlian dalam pengelolaan keuangan pelaksanaan pembangunan Jalan rabat beton, Mck, dan Drainase. Hal itu terjadi karena Pemerintah Desa tidak pernah menggunakan sumber daya manusia (SDM) yang ada di masyarakat sesuai dengan keahliannya. 
Pemanfaatan Sumber daya alam (SDA) serta pemanfaatan tenaga kerja lokal oleh pemerintah desa dalam pembangunan infrastruktur berupa pembangunan jalan rabat beton, MCK, dan Drainase itu belum dilaksanakan. Pemerintah Desa lebih menggunakan SDA berupa bahan material batu, pasir, dan kerikil dari luar desa dibandingkan yang ada di dalam Desa itu sendiri. Pemerintah Desa Bulalo juga lebih menggunakan tenaga kerja luar desa dibandingkan tenaga kerja dalam Desa untuk pembangunan jalan rabat beton, MCK, serta Drainase. Semua itu dilakukan oleh TPKD dan Pemerintah Desa karena dengan adanya selisih harga bahan material dan hari orang keja (HOK) dari luar desa dengan bahan material dan hari orang kerja (HOK) yang ada di dalam Desa.

Berdasarkan uraian fokus penelitian di atas menunjukan bahwa Perencanaan Kegiatan, Sumber daya manusia (SDM), serta Pemanfaatan Sumber Daya Alam (SDA) dan pemanfaatan tenaga kerja lokal adalah suatu faktor-faktor penghambat dalam pelaksanaan Gerakan Pembangun Desa (Gerbang Desa) melalui Program Pembangunan Infrastruktur di Desa Bulalo Kecamatan Kwandang Kabupaten Gorontalo Utara.

\section{SIMPULAN}

Berdasarkan deskripsi hasil penelitian yang telah diuraikan pada bagian lain, maka dapat disimpulkan sebagai berikut:

1. Dari segi Perencanaan Kegiatan yang dilakukan oleh Pemerintah Desa Belum maksimal dilaksanakan sebagai mana mestinya dengan ikut melibatkan masyarakat miskin dalam menentukan skala prioritas usulan yang akan dikerjakan, contohnya pembangunan jalan rabat beton, MCK, dan drainase;

2. Dari segi Sumber Daya Manusia (SDM) dan keahlian yang dimiliki oleh Tim Pelaksana Kegiatan Desa (TPKD) belum memenuhi syarat menjadi pelaksana kegiatan Desa contohnya seperti dasar pendidikan yang lulusan sekolah menengah pertema (SMP) serta tidak keahlian dalam pembangunan maupun pengelolaan keuangan;

3. Dari segi Pemanfaatan Sumber daya alam (SDA) serta pemanfaatan tebaga kerja lokal oleh pemerintah desa dalam pembangunan inprastruktur berupa pembangunan jalan rabat beton, MCK, dan Drainase itu belum dilaksanakan. Pemerintah Desa lebih menggunakan SDA berupa bahan material batu, pasir, dan kerikil dari luar desa dibandingkan yang ada di dalam Desa itu sendiri.

4. Berdasarkan uraian- uraian di atas maka dapat disimpulkan bahwa Perencanaan kegiatan, Sumber daya manusia (SDM), Pemanfaatan sumber daya alam (SDA) serta pemanfaatan tenaga kerja lokal adalah suatu faktorfaktor penghambat utama dalam pelaksanaan gerakan pemabangunan desa (Gerbang Desa) melalui Program Infrastruktur di Desa Bulalo Kecamatan Kwandang Kabupaten Gorontalo Utara. 


\section{S A R A N}

Sehubungan dengan simpulan yang diuraikan di atas, maka ada beberapa hal yang perlu disarankan kepada Pemerintah Desa Bulalo Kecamatan Kwandang demi tercapainya tujuan utama dari Gerakan Pembangunan Desa (Gerbang Desa) di Desa Bulalo di Kecamatan Kwandang Kabupaten Gorontalo Utara maka diperlukan melakukan beberapa hal antara lain:

1. Dalam Perencanaan Kegiatan yang dilakukan oleh Pemerintah Desa melalui Rapat Perencanaan Kegiatan demi menghasilkan usulan kegiatan yang sesuai dengan kebutuhan masyarakat miskin harus melibatkan masyarakat miskin dalam hal penentuan skala prioritas usulan yang akan dilakukan.

2. Pemerintah Desa Bulalo juga harus melibatkan masyarakat yang memiliki Sumber daya manusia (SDM) dan keahlian khusus untuk menjadi Tim Pelaksana Kegiatan Desa (TPKD) sehingga Pembangunan Desa bisa mencapai target yang telah ditentukan.

3. Pemerintah Desa Bulalo harus memanfaatkan potensi sumber daya alam (SDA) yang ada di Desa itu sendiri, serta melibatkan tenaga kerja lokal dalam pelaksanaan pekerjaan infrastruktur di Desa, dengan tujuan agar kiranya tingkat pendapatan ekonomi masyarakat meningkat, serta bisa melancarkan progres kegiatan pekerjaan sesuai dengan target yang telah ditentukan.

4. Pemerintah Daerah Kabupaten Gorontalo Utara dalam hal ini Dinas terkait dengan
Pembangunan Desa agar kiranya dapat memantau dan mengawasi semua tahapan pelaksanaan kegiatan pembangunan yang ada di Desa Bulalo Kecamatan Kwandang Kabupaten Gorontalo Utara.

\section{DAFTAR PUSTAKA}

Abdul Wahab, Solichin. 2008. Pengantar Analisis Kebijakan Publik. Malang: Universitas Muhamadiyah Malang Press.

Agustino, L. 2006. Politik \& Kebijakan Publik. Bandung: AIPI Bandung bekerja sama dengan Puslit KP2W Lemlit Unpad.

Agustino, Leo. 2008. Dasar-Dasar Kebijakan Publik. Bandung: Alfabeta

Agustino Leo. 2008. Dasar-dasar Kebijakan Publik. Bandung: Alfabeta

Moleong, Lexi. J. 2006. Metode Penelitian Kualitatif. Bandung: PT. Remaja Rosidakarya.

Muta'ali, L. 2011. Kapita Selekta Pengembangan Wilayah.

Yogyakarta: Badan Penerbit

Fakultas Geografi (BPFG) UGM.

--------. 2006. Metode Penelitian

Kualitatif Edisi Revisi.

Bandung: PT. Remaja

Rosdakarya.

---------. 2007. Metode Penelitian

Kualitatif. Edisi Revisi.

Bandung: PT. Remaja

Rosdakarya Offset.

Nugroho, D, Riant. 2003. Kebijakan

Publik:

Formulasi,

Implementasi dan Evaluasi. Jakarta: PT. Elex Media Komputindo.

Purwoto, H. Dan Kurniawan, D.A., 2009. Kajian Dampak 
Infrastruktur Jalan Terhadap

Pembangunan Ekonomi dan

Pengembangan Wilayah.

Simposium XII FSTPT 14

November 2009. Surabaya:

Universitas Kristen Petra.

Singiresu, S Rao dan John W.,

Newstorm. 2009. Perilaku

Dalam Organisasi. Alih

Bahasa Agus Dharma.

Jakarta: Erlangga.

Sugiyono. 2010. Metode Penelitian

Administrasi. Bandung:

Alfabeta.

2013. Memahami

Penelitian Kualitatif. Bandung:

Alfabeta.

Suharto, Edi. 2007. Kebijakan

Sosial sebagai Kebijakan

Publik. Bandung: Alfabeta.

Sastra dan Marlina. 2006.

Perencanaan dan

pengembangan perumahan.

Yogyakarta. Penerbit ANDI.

Suharto, Edi. 2006. Membangun

Masyarakat Memberdayakan

Rakyat. Bandung: PT. Refika

Aditama.

Suardi. 2010. Teori Kebijakan, Jakarta: Badan Penerbit Alam.

Suharno. 2010. Dasar-Dasar Kebijakan Publik

Yogyakarta: UNY Press.

Tangkilisan, Hessel Nogi S. 2008.

Kebijakan Publik Yang

Membumi. Yokyakarta:

Lukman Offeset \&

YPAPI.

\section{Dokumen lainnya:}

Undang-Undang Dasar tahun 1945

Peraturan menteri dalam negeri nomor 32 tahun 2004 tentang Desa

Direktorat Jenderal Penataan Ruang dan Departemen Pekerjaan Umum. 2009. Kamus Penataan
Ruang. Jakarta: Direktorat Jenderal Penataan Ruang dan Departemen Pekerjaan Umum. 